\title{
Weltrichia magna sp. nov., a new record for the Middle Jurassic of Oaxaca, Mexico
}

\author{
DIANA S. GUZMÁN-MADRID ${ }^{*}$ and MARÍA P. VELASCO-DE LEÓN ${ }^{1}$ \\ ${ }^{1}$ Colección de Paleontología, Facultad de Estudios Superiores Zaragoza, Universidad Nacional Autónoma \\ de México, Batalla 5 de Mayo s/n, Col. Ejército de Oriente, Iztapalapa, C.P. 09230. CDMX, México; \\ e-mail: dianaguz_8@yahoo.com.mx (DG-M), pativel@unam.mx (MV-L)
}

Received 17 February 2021; accepted for publication 11 June 2021

\begin{abstract}
The Jurassic locality San Juan Mixtepec (Zorrillo Formation in the state of Oaxaca) contains fossil plants of the order Bennettitales, mainly of the genus Zamites, as well as reproductive structures of the genera Williamsonia, Williamsoniella and Weltrichia, but male reproductive structures of the latter genus are scarce and almost restricted to the south of Mexico; they have also been reported in the Triassic of the north of Mexico. Here we report a new record for this locality and a new species of male reproductive structure of the genus Weltrichia. We recovered half of an adpression in fine-grained sandstone with the positive and negative of the adaxial part of the male reproductive structure, which when open measures $22.6 \mathrm{~cm}$ in diameter. A reconstruction suggests the presence of ten centrifugal rays that become thinner towards the acute apex and are fused in a central basal cup. The structure exhibits complete centrifugal rays with basal structures that are interpreted as insertion sites for pollen sacs. We employed acetate peel, mechanical separation and hydrofluoric acid (HF) maceration techniques for extraction of anatomical samples. We compared 13 morphological and 10 anatomical characters with previous records from localities in México, Europe, Asia and other parts of the world. We observed epidermal cells and syndetocheilic stomatal apparatuses, which corroborate an epidermal affinity to the Bennettitales. This new record would be the largest male reproductive structure found in the region thus far, and increases the distribution of Weltrichia in the Jurassic of Oaxaca.
\end{abstract}

KEYWORDS: Bennettitales, Williamsoniaceae, centrifugal rays, central cup

\section{INTRODUCTION}

A plant group within the gymnosperms that belongs to the order Bennettitales had a dominant distribution worldwide, with a stratigraphic range from the Triassic to the Cretaceous (Delevoryas, 1991; Parrish et al., 2004; Anderson et al., 2007; Taylor et al., 2009; Popa, 2014, 2019). It is the most abundant fossil plant group in Mexico, found mainly in strata from the Lower and Middle Jurassic; and the oldest records correspond to the Santa Clara Formation from the Upper Triassic (Carnian Norian) in the state of Sonora (Weber et al., 1980; Weber and Zambrano, 1985; Weber, 2008; Silva-Pineda et al., 2011; Velasco-de

\footnotetext{
Corresponding author
}

León et al., 2012). This order is divided into the families Cycadeoidaceae, based on vegetative and reproductive anatomy, and Williamsoniaceae, represented by uni- or bisexual reproductive organs, reproductive structures similar to flowers. The structures assigned to this family belong to the genera Williamsonia Carruthers, Wielandiella Nathorst emend Pott (female reproductive structures), Weltrichia Braun emend Harris (male reproductive structure) and Williamsoniella Thomas (bisexual reproductive structure) (Wieland, 1914; Person and Delevoryas, 1982; Silva-Pineda, 1984; Delevoryas, 1991; Anderson et al., 2007; Taylor et al., 2009; Silva-Pineda et al., 2011; Pott, 2014; Popa, 2014, 2019). According to previous 
reports, male reproductive structures are less frequent than female ones in the fossil record (Delevoryas, 1991; Silva-Pineda et al., 2011; Velasco-de León et al., 2012; Popa, 2014, 2019).

The genus Weltrichia has a stratigraphic range from the Triassic to the Cretaceous, with a distribution in Austria, China, France, South Africa and Ukraine (Triassic), and in Antarctica, the United States, India, England, Iran, Italy, Japan, Kazakhstan, Malaysia, Nepal and Romania (Jurassic) (Anderson et al., 2007; Velasco-de León et al., 2012; Popa, 2014, 2019). This genus is characterized by a central cup from which fused microsporophylls or centrifugal rays radially emanate, ornamented with ridges, striae and/or trichomes, with bivalve synangia or pollen sacs that contain elliptical and monocolpate pollen. They occasionally exhibit centripetal rays around the central cup, resiniferous bodies or attractants, and other ornamentation in both the microsporophylls and the central cup (Harris, 1969; Delevoryas, 1991; Anderson et al., 2007; Popa, 2019). The species of Weltrichia in Mexico are distributed in the Middle Jurassic strata of Oaxaca in the Ayuquila Formation (Campos-Madrigal, et al., 2013; formerly Tecomazuchil Fm) near the base of the Peña de Ayuquila, with records of $W$. ayuquilana Delevoryas and W. microdigitata Delevoryas (Delevoryas, 1991) as well as W. mixtequensis
Silva-Pineda, Velasco-de León, Arellano and Grimaldo (Silva-Pineda et al., 2011).

In the Jurassic locality of San Juan Mixtepec (Zorrillo Formation) in the state of Oaxaca there is an important presence of Bennettitales, mainly of the genus Zamites Brongniart, as well as reproductive structures of the genera Williamsonia, Williamsoniella and Weltrichia. However, records of male reproductive structures at species level are scarce and almost restricted to the Ayuquila Basin in the south of Mexico (Delevoryas, 1991; Silva-Pineda et al., 2011; Velasco-de León, et al., 2012; LozanoCarmona, 2017). This new record from the Middle Jurassic of the Zorrillo Formation in San Juan Mixtepec would be the southernmost species of the state of Oaxaca thus far, and will help determine the diversity of this genus in Mexico in the future.

\section{MATERIALS AND METHODS}

The specimen was discovered in San Juan Mixtepec, Tlaxiaco, in the northwestern part of the state of Oaxaca. The outcrop is $2 \mathrm{~km}$ southeast of the town of San Juan Mixtepec, on the bank of the Mixteco River $\left(17^{\circ} 17^{\prime} \mathrm{N}\right.$ and $97^{\circ} 48^{\prime} \mathrm{W}$ ) (Fig. 1a). The Zorrillo Formation has been dated to the Bathonian (Erben, 1956; Sandoval and Westermann, 1986). More general studies have been conducted in the Mixteco Terrane, which includes the Mixtepec region, for which a continental environment has been proposed (Morán-Zenteno et al.,

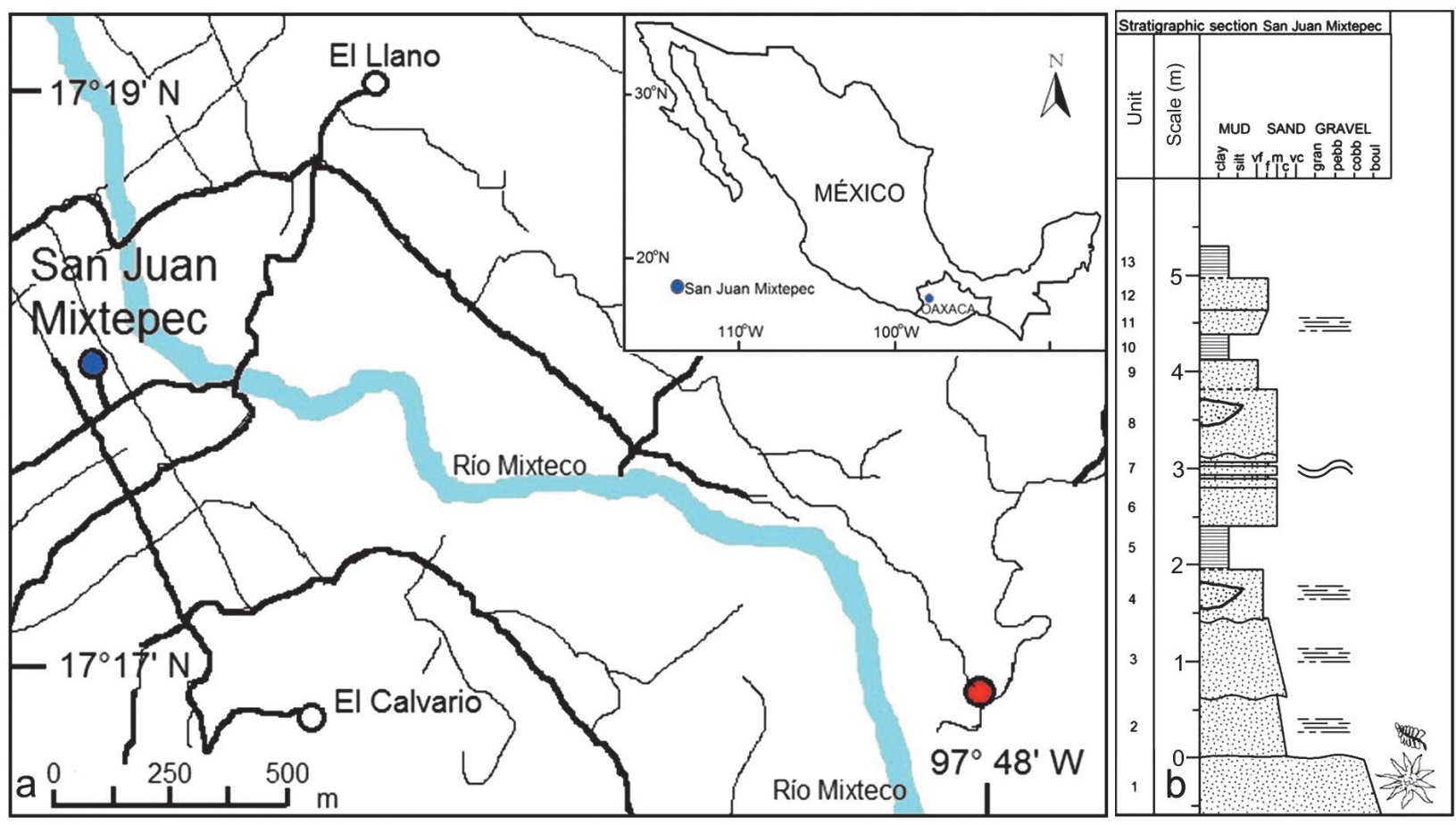

Fig. 1. Studied locality and stratigraphic section. a. Studied locality (red dot). b. Stratigraphic section of the San Juan Mixtepec locality 
1993). In the study locality, Lozano-Carmona (2017) measured the column and noted that the base of the outcrop is of sedimentary origin and is $223 \mathrm{~m}$ thick. It is correlated with the Cualac Formation and is in discordant and erosional contact with the Acatlán Complex. In concordant basal contact it is overlain by a finer sedimentary sequence that, consists of intercalations of fine to medium yellow-ocher sandstone, dark grey lutite, and carbon lenses; the sequence has a partial thickness of $145 \mathrm{~m}$. This sequence is interpreted as being part of the lower unit of the Tecocoyunca Group, Zorrillo Formation, dating to the middle Jurassic (Bajocian), with fossiliferous layers located between the eighth and tenth meters of column thickness. Undulating strata of carbon, lutite and fine sandstone, tool marks, ripples, cross-lamination, and increasing and composite gradation have also been identified.

Material had been collected previously in a sequence $5.5 \mathrm{~m}$ thick, while the studied specimen was collected in an underlying stratum, $40 \mathrm{~cm}$ from this sequence (Fig. 1b). We recovered half of an open male reproductive structure in adaxial view in finegrained sandstone. The adpression was extracted with the positive and the negative parts; adpressions generally lack a cuticle but we were able to obtain fragments. We described and measured the morphological characters and made a reconstruction of the structure. Extraction of cuticle fragments recovered from some centrifugal rays and the cup helped to identify its anatomical characters (Guzmán-Madrid et al., 2019). The specimen and cuticular samples are deposited in the Paleontological Collection of the Facultad de Estudios Superiores Zaragoza of the National Autonomous University of Mexico under the acronym CFZ M102.

The material was observed under an Olympus SZ51 stereomicroscope and photographed with an Olympus Stylus Tough-6020 digital camera. We used acetate peel, mechanical separation, and 10\% hydrofluoric acid (HF) maceration techniques to extract the anatomical samples. The cuticles were treated with $40 \%$ nitric acid $\left(\mathrm{HNO}_{3}\right)$ and $5 \%$ ammonium hydroxide $\left(\mathrm{NH}_{4} \mathrm{OH}\right)$, bleached with $3.5 \%$ hydrogen peroxide $\left(\mathrm{H}_{2} \mathrm{O}_{2}\right)$, washed with distilled water, and suspended in 5\% glycerin (Kerp, 1990; Kouwenberg et al., 2007; Guzmán-Madrid, 2016; Guzmán-Madrid et al., 2019). The samples were observed fresh under an Olympus BX41 optical microscope (OM) and photographed with an Olympus E-620 digital camera. Morphological and anatomical measurements of the specimen were made in ImageJ ver. $1.38 \mathrm{x}$. We then observed and photographed them using a Hitachi SU1510 scanning electron microscope (SEM).

We examined the records of 25 valid species of the genus Weltrichia dated to the Triassic and Jurassic present in localities of Mexico (Person and Delevoryas, 1982; Delevoryas, 1991; Silva-Pineda, et al., 2011; Velasco-de León et al., 2012), Europe (Harris, 1969; Popa, 2014, 2019), Antarctica, Asia, the United States and South Africa (Sitholey and Bose, 1953; Kimura and Ohana, 1989; Sun et al., 2001; Schweitzer and Kirchner, 2003; Li et al., 2004; Anderson et al., 2007; Popa, 2014, 2019), and compared their morphological and anatomical characteristics with the specimen from San Juan Mixtepec. We used the terminology of Harris (1969) and Popa $(2014,2019)$ for the descriptions of all characters.

\section{RESULTS}

\section{SYSTEMATIC PALEOBOTANY}

\section{Order BENNETTITALES Engler, 1892}

\author{
Family WILLIAMSONIACEAE \\ (Carruthers) Nathorst, 1913
}

Genus Weltrichia

Braun, 1847 emend. Harris, 1969

Type species: Weltrichia mirabilis

Braun, 1847, from the Jurassic of Veitlahm (Bavaria), Germany

\section{Weltrichia magna Guzmán-Madrid et Velasco-de León, sp. nov.}

Holotype. No. CFZ M102 positive and negative (Pl. 1, figs 1-11), (Pl. 2, figs 1-12) MO and SEM.

Repository. Deposited in the Paleontological Collection of the Facultad de Estudios Superiores (FES) Zaragoza of the National Autonomous University of Mexico (UNAM).

Type locality. On the bank of the Mixteco River, San Juan Mixtepec, Oaxaca.

Stratigraphy horizon. Middle Jurassic, Bajocian.

Etymology. The specific epithet refers to its characteristic size (from the Latin magnus, feminine magna = large).

Diagnosis. Male reproductive structure with a central fibrous cup of very small size as compared to the length of the rays, with a long peduncle. It exhibits ten centrifugal rays, slightly curved, with an acute apex, thin veins and striae, and moderately deep scars towards the base of the rays. Short, basal centripetal rays. The cuticle of the centrifugal rays and the cup has longitudinal epidermal cells, from rectangular to isodiametric, with straight, undulating and sinuous walls. The cuticle of the cup shows hair bases. Syndetocheilic stomatal apparatus.

Description. Half of an adaxial adpression of a male reproductive structure measuring $22.6 \mathrm{~cm}$ in diameter, fibrous central cup $3.7 \mathrm{~cm}$ in adaxial diameter, inner rim $2.3 \mathrm{~cm}$, lateral 

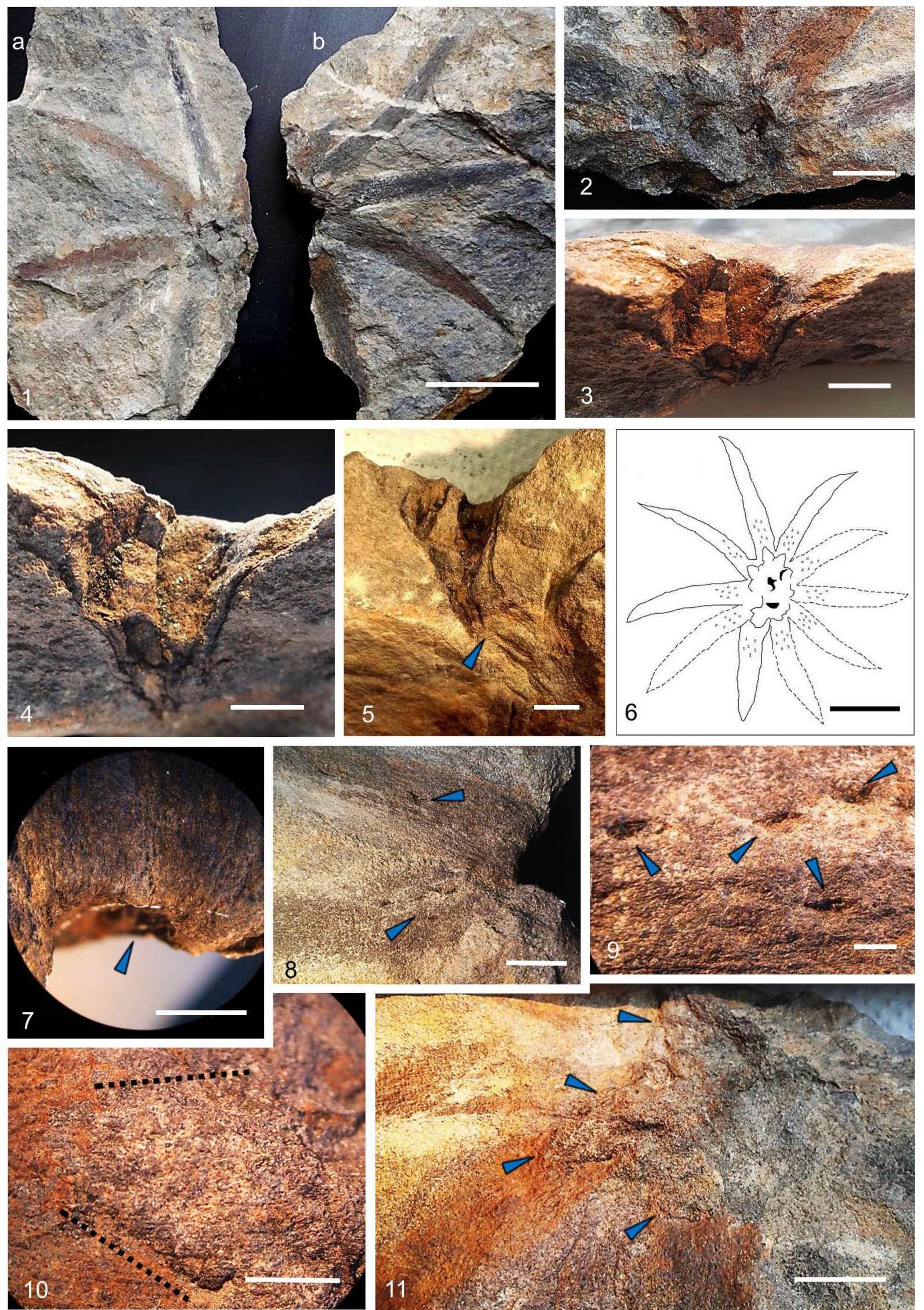

Plate 1. 1 Morphology of Weltrichia magna sp. nov. 1. a, b. Adaxial view, negative and positive; 2. Adaxial view of cup; 3. Lateral internal view of cup and part of fused rays; 4. Cup depth; 5 . Lateral view showing cup and peduncle (arrowhead); 6. Drawing of adaxial view; 7. Detail showing fusion of centrifugal rays to cup (arrowhead); 8. Insertion scars in centrifugal rays (arrowheads); 9. Detail of scars; 10. Detail of centripetal ray (dotted line); 11. Centripetal rays around cup and at base of centrifugal rays. Scale bars: $1,6=5 \mathrm{~cm} ; 2,3,5,11=2 \mathrm{~cm} ; 4,7,8=1 \mathrm{~cm} ; 10=0.5 \mathrm{~cm} ; 9=0.2 \mathrm{~cm}$ 

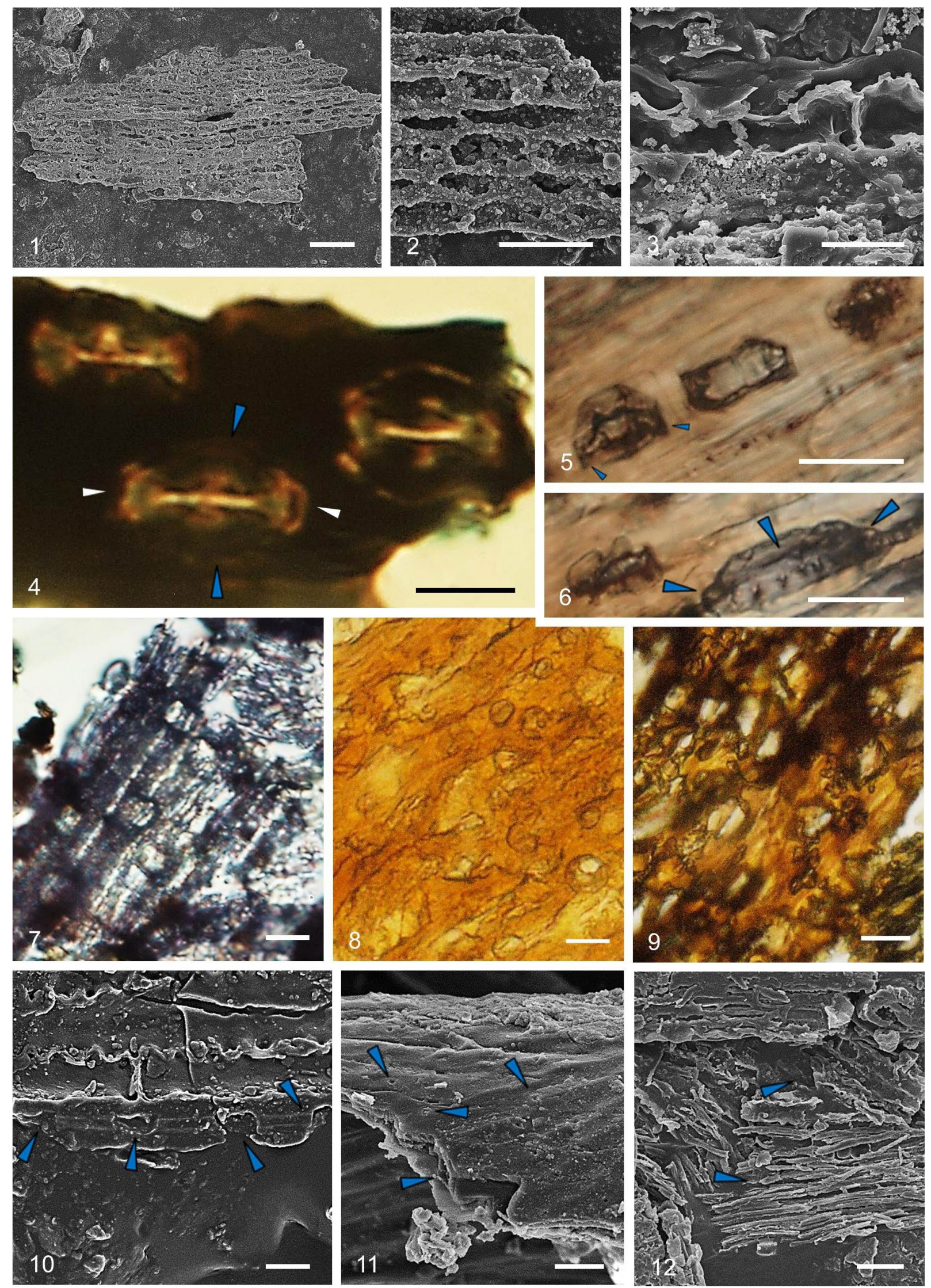

Plate 2. Cuticle of centrifugal rays and cup of Weltrichia magna sp. nov. 1-3. Epidermal cells in center and margin of ray; 4. Marginal syndetochelic stomata in center of ray, showing occlusive cells (blue arrowheads) and subsidiary cells (white arrowheads); $\mathbf{5}, \mathbf{6}$. Adaxial and lateral views of stomata of ray, showing ostiole, occlusive and subsidiary cells (arrowheads); 7. Stomata in longitudinal rows and interspersed in base of ray; 8, 9. Cup cuticle with dispersed stomata; 10. Cup cuticle with sinuous epidermal cells and row of stomata (arrowheads); 11. Detail showing thickness of cuticle and hair bases in cup (arrowheads); 12. Fibrous material in insertion scars (arrowheads). MEB: 1, 2, 3, 10, 11, 12; MO: 4-9; Scale bars: $1=50 \mu \mathrm{m} ; 2,5,7-10,12=20 \mu \mathrm{m} ; 3,4,6,11=10 \mu \mathrm{m}$ 
width $2.5 \mathrm{~cm}$ and depth $3 \mathrm{~cm}$ (Pl. 1, figs 1-5). Peduncle $9 \mathrm{~mm}$ wide and $6 \mathrm{~cm}$ long (Pl. 1, fig. 5). Ten radially fused rays originated from the cup (the reconstruction suggests 10 rays in total); (Pl. 1, figs 6, 7), $1.3-1.5 \mathrm{~cm}$ wide at base and 9-10.2 cm long, becoming thinner towards tip, with slight outward curvature towards the acute apex (Pl. 1, fig. 1a, b); fine longitudinal veins and striae observed along centrifugal rays, as well as 6-8 basal, elliptical, moderately deep and irregularly arranged scars probably corresponding to scars of pollen sacs ( $\mathrm{Pl}$. 1, figs 8,9 ). Maximum apical distance between centrifugal rays $5-8.4 \mathrm{~cm}$, distance between centripetal rays $2-2.2 \mathrm{~cm}$, rays $0.7-1.1 \mathrm{~cm}$ wide and 1-1.4 cm long, triangular, with fine longitudinal striae (Pl. 1, figs 1, 10, 11). Cuticle of centrifugal rays exhibits epidermal cells longitudinal to veins (with variation of shape and size along ray), rectangular, 7-9.5 $\mu \mathrm{m}$ wide and 26.6$35.5 \mu \mathrm{m}$ long, with straight walls $3.5-5.9 \mu \mathrm{m}$ wide at base of ray; rectangular, quadrangular, and isodiametric epidermal cells 3.4-14.5 $\mu \mathrm{m}$ wide and 8.7-47.8 $\mu \mathrm{m}$ long, with slightly undulating walls $1-1.8 \mu \mathrm{m}$ wide towards center and margin of ray; and rectangular epidermal cells 6.1-9 $\mu \mathrm{m}$ wide and 22-27.4 $\mu \mathrm{m}$ long, with sinuous walls $1.4-1.7 \mu \mathrm{m}$ wide towards ray apex and in veins (Pl. 2, figs 1-3). Oval syndetocheilic stomatal apparatus, 12-14 $\mu \mathrm{m}$ wide and 15-19 $\mu \mathrm{m}$ long, with slightly open ostioles $1.4-3 \mu \mathrm{m}$ wide and $8-13.8 \mu \mathrm{m}$ long. With two occlusive cells 3.6-5 $\mu \mathrm{m}$ wide and 12-15 $\mu \mathrm{m}$ long, and two opposite subsidiary cells $3.5-4.9 \mu \mathrm{m}$ and $6.1-$ $8.6 \mu \mathrm{m}$ long (Pl. 2, figs 4-6). Epidermal cells usually more elongated inside central cup than in centrifugal rays, undulating to sinuous, up to $17 \mu \mathrm{m}$ wide and $69 \mu \mathrm{m}$ long, with thickened walls 2.4-3.3 $\mu \mathrm{m}$ wide. Stomata in centrifugal rays and cup slightly sunken, irregularly arranged, occasionally arranged in rows and interspersed (Pl. 2, figs 7-10). Cuticle of internal central cup 1-4.9 $\mu \mathrm{m}$ thick, with hair bases 1-1.6 $\mu \mathrm{m}$ in diameter (Pl. 2, fig. 11). Cuticle exhibits fibrous material in insertion scars, in fine basal striae of centrifugal rays, and inside central cup (Pl. 2, fig. 12).

\section{REMARKS}

The male structure W. magna sp. nov. was found in a stratum associated with fragmented leaves of the genus Zamites. In the same layer we found a leaf of $Z$. lucerensis next to the structure.

\section{MORPHOLOGY}

We examined the records of male reproductive structures from the Middle Jurassic of Oaxaca present in the Ayuquila Basin and compared their morphological characters with Weltrichia magna sp. nov. Thus far there have been no records of cuticular preservation or anatomical analysis of the species from Oaxaca (Tab. 1).

Table 1. Comparison of 13 morphological characters of Weltrichia magna sp. nov. with previous records in localities from the Middle Jurassic of Oaxaca

\begin{tabular}{|c|c|c|c|c|}
\hline Weltrichia & $\begin{array}{c}\text { W. magna sp. nov. } \\
\text { Guzmán-Madrid et } \\
\text { Velasco-de León, } 2021\end{array}$ & $\begin{array}{c}\text { W. mixtequensis } \\
\text { Silva-Pineda, Velasco- } \\
\text { de León, Arellano et } \\
\text { Grimaldo, } 2011\end{array}$ & $\begin{array}{l}\text { W. microdigitata } \\
\text { Delevoryas, } 1991\end{array}$ & $\begin{array}{c}\text { W. ayuquilana } \\
\text { Delevoryas, } 1991\end{array}$ \\
\hline Localities & San Juan Mixtepec & Ayuquila town & Peña de Ayuquila & Peña de Ayuquila \\
\hline Age & Middle Jurassic & Middle Jurassic & Middle Jurassic & Middle Jurassic \\
\hline State & Oaxaca & Oaxaca & Oaxaca & Oaxaca \\
\hline Diameter & $22.6 \mathrm{~cm}$ & $7.5-8 \mathrm{~cm}$ & $3 \mathrm{~cm}$ & $3-6 \mathrm{~cm}$ \\
\hline Cup center & $3.7 \mathrm{~cm}$ & - & - & $3 \mathrm{~cm}$ \\
\hline Rim / cup center & $2.3 \mathrm{~cm}$ & $2.3-3 \mathrm{~cm}$ & $1.5 \mathrm{~cm}$ & - \\
\hline Base width & $2.5 \mathrm{~cm}$ & $2 \mathrm{~cm}$ & $1.5 \mathrm{~cm}$ & - \\
\hline Height & $3 \mathrm{~cm}$ & $2-2.5 \mathrm{~cm}$ & - & - \\
\hline Peduncle width & $0.9 \mathrm{~cm}$ & - & - & $?$ \\
\hline Peduncle length & $6 \mathrm{~cm}$ & - & - & - \\
\hline \# Centrifugal rays & $5(10)$ & $7(14)$ & 14 & 10 \\
\hline Centrifugal ray length & $9-10.2 \mathrm{~cm}$ & $7.6 \mathrm{~cm}$ & $0.7-0.8 \mathrm{~cm}$ & $1.5 \mathrm{~cm}$ \\
\hline Centrifugal ray width & $1.3-1.5 \mathrm{~cm}$ & $0.7-0.9 \mathrm{~cm}$ & - & - \\
\hline Trichomes & No & Yes & No & No \\
\hline Ornamentation & Striae, scars & Striae & Median ridge & Median ridge, scars \\
\hline Pollen sacs & $?$ & Yes & Yes & Yes \\
\hline
\end{tabular}


Among the evaluated morphological differences, the size of Weltrichia magna sp. nov. is notable, measuring $22.6 \mathrm{~cm}$ in diameter: it is the largest unisexual reproductive structure found in Mexico. The male structures W. mixtequensis, W. microdigitata and W. ayuquilana are considerably smaller, measuring between 3 and $8 \mathrm{~cm}$ in diameter, with centrifugal rays with acute apexes and varying in shape, $7.6 \mathrm{~cm}$ long in W. mixtequensis and smaller than the compared species, measuring between $0.7 \mathrm{~cm}$ and $2 \mathrm{~cm}$ in length. The centrifugal rays in W. magna sp. nov. exhibit a slight downward curvature towards the acute apex and measure up to $10.2 \mathrm{~cm}$ in length. From the proportional measurements we infer that there are ten centrifugal rays. W. mixtequensis and W. microdigitata, which are smaller male reproductive structure, have more rays (14-20) than W. magna and W. ayuquilana (10); the latter is also small. We observed a peduncle and centripetal rays in $W$. magna sp. nov., which are not visible in the other species. It has longitudinal striae in the rays, as in W. mixtequensis, and basal scars that differ in shape and depth from those in W. ayuquilana.

The size and depth of the scars of W. magna sp. nov., and the fibrous material inside them, suggest the likely insertion of pollen sacs that were not preserved due to some taphonomic event, unlike in W. ayuquilana, W. microdigitata and W. mixtequensis. The thick cuticle in the central cup, with small hair bases, and the presence of centripetal rays in the base of the centrifugal rays, serve a protective function in the cup, since centripetal rays are related to the protection of resiniferous bodies or attractants inside the cup (Popa, 2014, 2019). However, the internal carbonization of the cup in W. magna prevents observation of these structures.

We subsequently examined the records of valid Weltrichia species distributed in different localities of Europe and Asia and with an age range from the Late Triassic to the Late Jurassic, and compared their morphological characteristics with Weltrichia magna sp. nov. (Tab. 2).

The comparison of the different species of Weltrichia indicates great variation in morphology, ornamentation, and the size of both the cup and the centrifugal rays, as well as the conservation of pollen sacs and other structures. It is important to note that some species lack comparable characters due to their conservation: for example, Weltrichia oolithica Saporta
1891, whose total number of centrifugal rays is unknown, and Weltrichia primaeva Schweitzer et Kirchner 2003, for which there are only fragments of centrifugal rays (Popa, 2014). The lithology, taphonomic processes, and state of development in which they were found can also complicate a comparison of characters. However, W. magna sp. nov. can be clearly distinguished from all the examined male structures.

One distinct characteristic of Weltrichia magna sp. nov. is the diameter of the whole structure, measuring $22.6 \mathrm{~cm}$, with an affinity to W. santalensis (Sitholey et Bose) Harris, which measures up to $23 \mathrm{~cm}$, and $W$. sol Harris, measuring up to $20 \mathrm{~cm}$. The diameter of the cup of the new species measures $3.7 \mathrm{~cm}$, as compared to the $10 \mathrm{~cm}$ cup diameter of $W$. sol. The adaxially exposed centrifugal rays of $W$. magna sp. nov. reveal a slight curvature towards the exterior of the cup (Pl. 1, fig. 1a, b); in other species this curvature has only been described towards the interior of the cup, as in W. fabrei Saporta, W. mirabilis Braun and W. whitbiensis (Nathorst) Harris. The centrifugal rays can measure up to $10.2 \mathrm{~cm}$ in length and $1.5 \mathrm{~cm}$ in width, a characteristic that shows affinity to $W$. santalensis, having rays approximately $10 \mathrm{~cm}$ long and $2 \mathrm{~cm}$ wide. Regarding the number of centrifugal rays, W. magna sp. nov. and the species $W$. antonii Popa, W. ayuquilana Delevoryas, W. johannae Popa, W. mirabilis, W. oolithica Saporta, W. pecten (Leckenby) Harris and W. steierdorfensis Popa exhibit between 9 and 12 centrifugal rays; they are the species with the lowest number of rays.

Weltrichia magna sp. nov. shows fine longitudinal veins and striae running along the centrifugal rays, and a fibrous and moderately rigid surface. Albeit with a different arrangement and thickness, this type of ornamentation can also be observed in W. daohugouensis Li, W. fabrei, W. harrisiana Bose et Banerji, W. hirsuta Schweitzer, W. mirabilis, W. oolithica, W. pecten, W. santalensis, W. sp. Kimura et Ohana, W. spectabilis (Nathorst) Harris and W. whitbiensis. At the base of the centrifugal rays we observe elliptical, elongated and moderately deep scars in groups of six to eight, which contrasts with the circular to elliptical scars found in pairs in W. givulescui Popa (Popa, 2001). These scars have been inferred as corresponding to rudimentary or immature pollen sacs, as in $W$. sol, according to the description by Harris (1969). However, the basal scars in 


\begin{tabular}{|c|c|c|c|c|c|c|c|c|c|c|c|c|c|c|c|c|c|c|c|c|c|}
\hline ही & a. & $\mathrm{z}$ & $\mathrm{z} z$ & $\Rightarrow$ & $>0$ & a. & $\gg$ & $\lambda$ & $\lambda$ & $z>$ & $>1$ & $\lambda \mid \lambda$ & 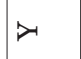 & $\triangle>$ & $\lambda$ & $\succ$ & $\succ$ & z & $\gg$ & & $\lambda$ \\
\hline 0 & 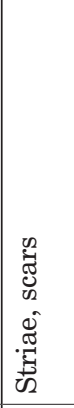 & $\mid$ & 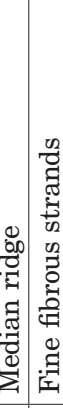 & 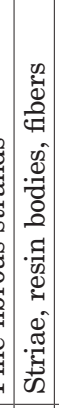 & . & 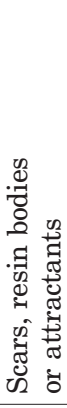 & 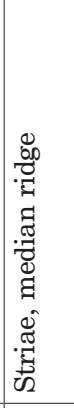 & 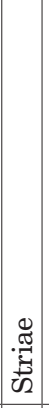 & 1 & 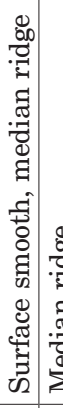 & 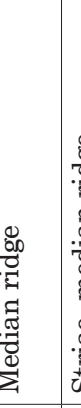 & 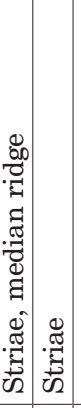 & 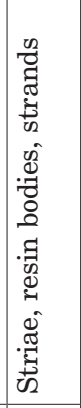 & 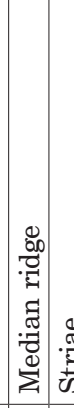 & 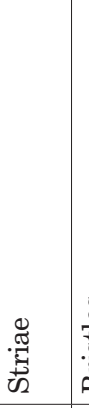 & 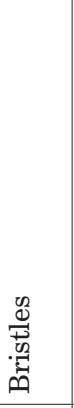 & 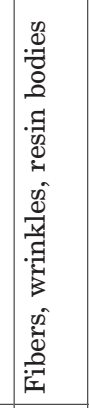 & 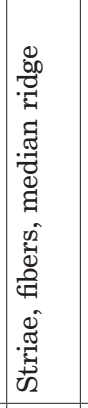 & 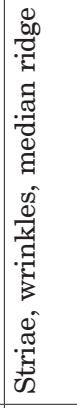 & 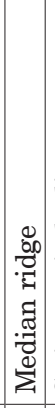 & 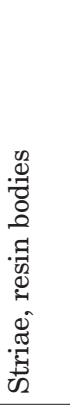 \\
\hline$E$ & z & 1 & \begin{tabular}{c|c}
0. & 1
\end{tabular} & $\lambda$ & 1 & 1 & 1 & $\lambda$ & I & 1 & 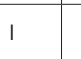 & \begin{tabular}{l|l|}
1 & 1 \\
\end{tabular} & 1 & 11 & 1 & $\lambda$ & 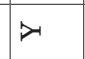 & $\mathrm{z}$ & z & 1 & z \\
\hline$\approx$ & 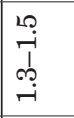 & \begin{tabular}{l} 
\\
\multirow{2}{*}{} \\
\\
- \\
\end{tabular} & a. & $\begin{array}{c}20 \\
0 \\
\vdots \\
\vdots \\
0 \\
0\end{array}$ & $\begin{array}{ll}7 & \\
0 \\
0 \\
0\end{array}$ & $\begin{array}{l}i \\
\stackrel{1}{0} \\
0\end{array}$ & $\begin{array}{l}\infty \\
0 \\
0 \\
1 \\
0 \\
0 \\
0\end{array}$ & a. & 1 & 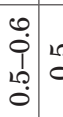 & $\stackrel{10}{\circ}$ & a. $a$. & $\mid \begin{array}{l}1 \\
1 \\
20 \\
0\end{array}$ & $\stackrel{\leftrightarrow}{\circ}$ ๑ & a. & 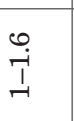 & $\neg$ & -1 & -1 & 1 & -1 \\
\hline$\vec{x}$ & $\begin{array}{l}0 \\
0 \\
0 \\
1 \\
0 \\
\end{array}$ & \begin{tabular}{|c|} 
\\
$\infty$ \\
$\infty$ \\
$\infty$ \\
$\infty$
\end{tabular} & a. & $\begin{array}{l}20 \\
i \\
\vdots \\
\sim \\
\sim\end{array}$ & $\begin{array}{cc}0 \\
0 \\
10\end{array}$ & f & $\begin{array}{l}10 \\
\infty \\
10 \\
20 \\
0 \\
0\end{array}$ & 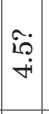 & 1 & 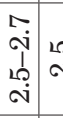 & L̊ & \begin{tabular}{c|c}
71 \\
$\infty$
\end{tabular} & $\infty$ & $0=$ & 윽 & j & $\begin{array}{l}0 \\
1 \\
1\end{array}$ & $\stackrel{\check{\infty}}{\infty}$ & $\begin{array}{l}10 \\
0 \\
0\end{array}$ & $\left|\begin{array}{l}20 \\
\mathrm{i}\end{array}\right|$ & $r$ \\
\hline 䓌 & 옳 & $\begin{array}{l}* \\
1 \\
\infty \\
-1\end{array}$ & $\exists \mid \begin{array}{l}\frac{1}{1} \\
0\end{array}$ & 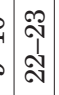 & $\tilde{i}$ & $\stackrel{\varphi}{\sim}$ & $\begin{array}{l}\underset{1}{1} \\
\underset{\sim}{\prime}\end{array}$ & i & 1 & 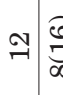 & $\underset{\infty}{0}$ & $\begin{array}{cc}\overrightarrow{1} \\
\stackrel{0}{0}\end{array}$ & 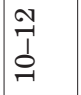 & a. & จ & สิ & 网 & $\begin{array}{l}0 \\
71 \\
10 \\
-1\end{array}$ & $\dddot{9}$ & 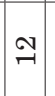 & \begin{tabular}{l}
0 \\
\multicolumn{1}{c}{} \\
$\underline{9}$
\end{tabular} \\
\hline $\overrightarrow{a_{1}}$ & 0 & 1 & a. 1 & 1 & 1 & 1 & 1 & 1 & N & 1 & 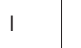 & \begin{tabular}{l|l}
1 & 1
\end{tabular} & 1 & a. & a. & 1 & 1 & 1 & a. & 1 & 1 \\
\hline ๓ి & $:$ & 1 & a. 1 & 1 & 1 & 1 & 1 & a. & ت艹 & 1 & 1 & $\begin{array}{lll}1 & 1\end{array}$ & 1 & a. 1 & 1 & 1 & 1 & 1 & r. & 1 & 1 \\
\hline 朵 & $\infty$ & -1 & a. & 1 & a. & & 1 & 1 & $\sim$ & 12 & تَ & \begin{tabular}{l|l|} 
N & 1
\end{tabular} & 1 & $\therefore$. & 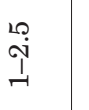 & 1 & $\begin{array}{l}\infty \\
1 \\
1\end{array}$ & 1 & $\infty$ & & 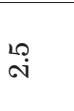 \\
\hline$\stackrel{n}{\infty}$ & $\begin{array}{l}10 \\
i \\
i\end{array}$ & 1 & $\begin{array}{c}a .1 \\
\text { a. }\end{array}$ & 1 & $\underset{\sim}{\stackrel{N}{*}}$ & $\dashv$ & 1 & 1 & I & 11 & 1 & \begin{tabular}{l|l|}
1 & 1 \\
\end{tabular} & 1 & a. 1 & 1 & 1 & 1 & 1 & 1 & -1 & 1 \\
\hline ن & $\stackrel{\sim}{\infty}$ & 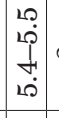 & a. & $\begin{array}{l}L \\
0 \\
0 \\
+ \\
+\end{array}$ & 1 & $\underset{b}{t}$ & N & 10 & مُ & ๑ & N & $10 \%$ & L & a. & 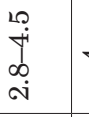 & tr & $\stackrel{9}{\circ}$ & $\widehat{\grave{i}}$ & H & & L \\
\hline$\ddot{n}$ & $\begin{array}{l}0 \\
\stackrel{\text { N }}{\text { N. }}\end{array}$ & ㄱ. & 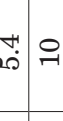 & $\mid \begin{array}{l}0 \\
0 \\
0 \\
0 \\
0 \\
0\end{array}$ & a. & $\begin{array}{l}0 \\
\\
\infty\end{array}$ & \begin{tabular}{l}
10 \\
7 \\
\multirow{1}{1}{}
\end{tabular} & 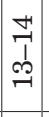 & I & $1 \AA$ & $\hat{\imath}$ & $\circ$ 웍 & $\underset{\sim}{\sim}$ & ฉ. & $\begin{array}{l}\text { ఇ } \\
\text { ָे } \\
\text { Nิ }\end{array}$ & $\stackrel{\mathfrak{N}}{\mathcal{F}}$ & 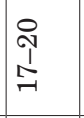 & $\stackrel{9}{\circ}$ & $\underset{I}{I}$ & & $\begin{array}{l}\stackrel{9}{1} \\
\stackrel{1}{\mathcal{I}} \\
\end{array}$ \\
\hline $\begin{array}{l}\text { D. } \\
\text { : } \\
0\end{array}$ & 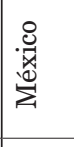 & | & 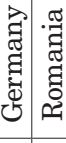 & : & $\mid$ & 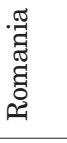 & : & 跑 & .ี & 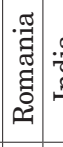 & $\tau$ & 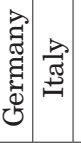 & 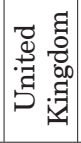 & & : & 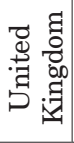 & 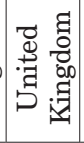 & 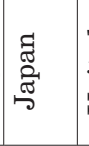 & 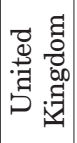 & & 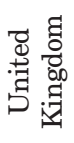 \\
\hline$\underset{4}{\stackrel{8}{4}}$ & 公 & ه & 国 & 方 & $H$ & 月 & 流 & 曰 & B & 今尚 & p & 今引 & 流 & & 孛 & 忘 & 㳘 & b & 茫 & & 产 \\
\hline $\begin{array}{l}\text { 总 } \\
\text { 胥 } \\
\stackrel{9}{9}\end{array}$ & 窇 & 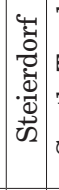 & 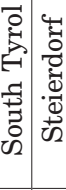 & 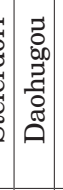 & 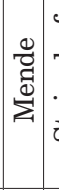 & 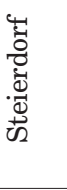 & 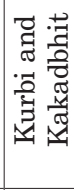 & 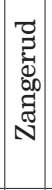 & . & 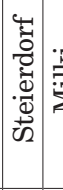 & 过 & 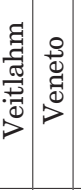 & 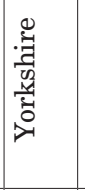 & & 苛 & 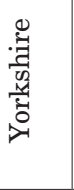 & 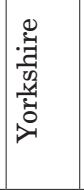 & 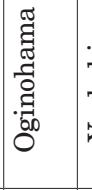 & 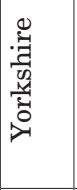 & & 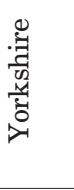 \\
\hline 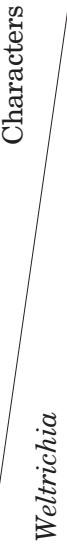 & 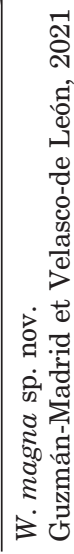 & 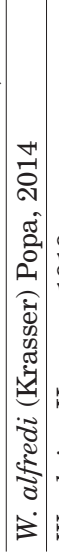 & 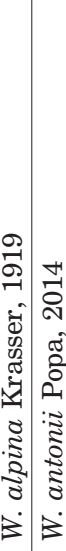 & 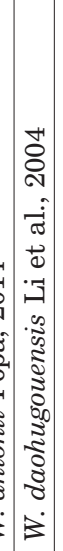 & 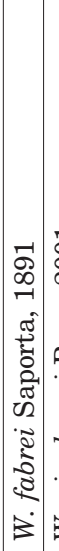 & 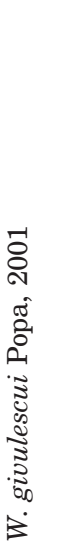 & 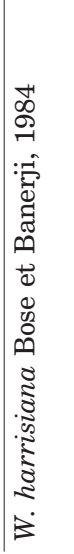 & 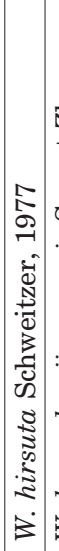 & 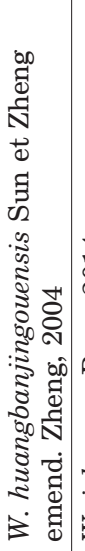 & 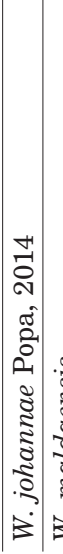 & 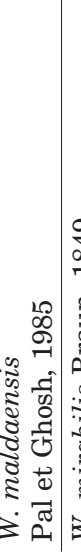 & 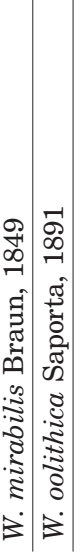 & 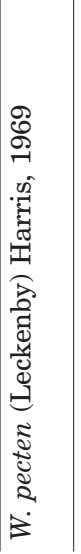 & 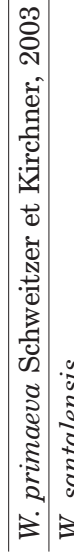 & 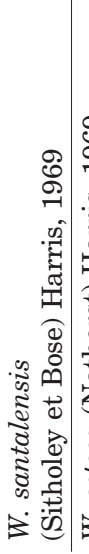 & 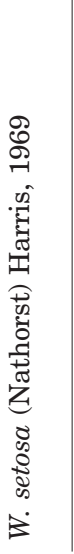 & 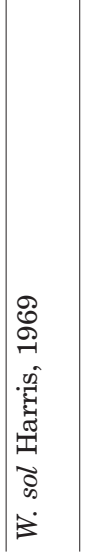 & 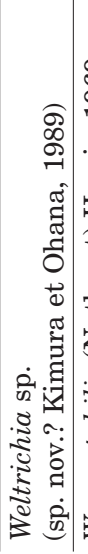 & 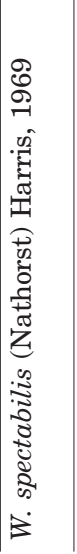 & 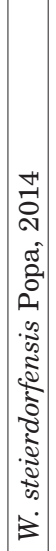 & 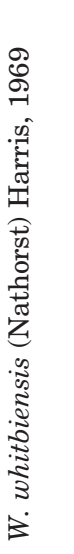 \\
\hline
\end{tabular}


the centrifugal rays of $W$. magna sp. nov. may correspond to poorly preserved pollen sacs, as occurs in $W$. givulescui. The structural fragility and loss of pollen sacs, as well as the developmental state of the living structure, have already been mentioned by Harris (1969) and Popa (2014). It is important to note that the species W. steierdorfensis, W. sp., W. johannae, W. antonii, W. alpina Krasser and W. alfredi (Krasser) Popa, besides lacking pollen sacs, also lack insertion scars in the centrifugal rays and the central cup. Even though we only recovered the positive and negative of half of an adaxial cone of $W$. magna sp. nov., its position and inclusion in fine-grained sandstone allowed conservation of the longitudinal inner part of the central cup, with a peduncle $0.9 \mathrm{~cm}$ wide, as reported in $W$. huangbanjingouensis Sun et al., having a peduncle $2 \mathrm{~cm}$ long. We also observed four centripetal rays located at the base of the centrifugal rays, which are structures reported in W. givulescui, W. johannae and W. setosa. These characteristics are rarely preserved.

\section{CUTICULAR STRUCTURE}

We were able to compare preserved epidermal characters only with Weltrichia pecten, W. setosa, W. sol, W. spectabilis and W. whitbiensis. According to the anatomical descriptions by Harris (1969), Delevoryas (1991) and Popa (2014, 2019), Weltrichia is characterized by the presence of syndetocheilic stomatal apparatuses with subsidiary cells opposite the guard cells, which are characteristics present in W. magna sp. nov. that corroborate its epidermal affinity to the genus. In addition, the epidermal cells are rectangular, as in $W$. setosa, quadrangular as in W. spectabilis, and isodiametric with straight, slightly undulating walls as in $W$. sol, and with sinuous walls as in W. whitbiensis. However, in W. magna sp. nov. the shape of the epidermal cells and the cell walls varies according to their position along the centrifugal rays and the central cup. The stomata are irregularly positioned and occasionally arranged in rows in the rays or interspersed in the fibers of the central cup. Trichomes are not visible in the cone or hairs in the centrifugal rays, as in Weltrichia mixtequensis; however, trichome bases can be observed in the epidermis of the central cup, which has not been reported thus far. We also observed fibrous material in the striae of the rays as reported by Harris (1969) in W. pecten, in the insertion scars, and inside the central cup, which corresponds to a slightly woody and strongly striated surface, also mentioned by Popa (2014).

\section{PALEOBIOLOGY \\ OF WELTRICHIA MAGNA SP. NOV.}

The morphological and anatomical characteristics of Weltrichia magna sp. nov., and the vertical and erect position of the specimen on a long peduncle of rigid appearance, suggest that it was a strong supporting structure, slightly woody on the exterior and fibrous in the basal part of the centrifugal rays and the interior of the central cup. We propose that its main function was to disseminate pollen for reproductive purposes or through a pollination mechanism (anemophilous, hydrophilous or entomophilous), previously discussed by several authors (Labandeira, 1997, 1998; Ollerton, 1999; Popa, 2014; Pott, 2014; Pott et al., 2016; Peris et al., 2017). As mentioned before, the structurally fragile and easily removable pollen sacs protected in simple appendages (Harris, 1969; Popa, 2014, 2019), as well as the curved morphology in the apexes of the centrifugal rays, lead us to infer, from its adaxial position (Popa, 2014), anemophilous and hydrophilous pollen dispersal (Fig. 2a-d).

The thick cuticle in the central cup, with small hair bases and the presence of centripetal rays at the base of the centrifugal rays, serve a protective function in the cup, since centripetal rays are related to protection of resiniferous bodies or attractants inside the cup (Popa, 2014, 2019).

\section{CONCLUSIONS}

Our comparison of Weltrichia magna sp. nov. from the San Juan Mixtepec locality with other species of male reproductive structure from localities of Oaxaca and from Asia and Europe allowed us to identify distinct morphological characters, such as the shape and size of the reproductive structure, which is the largest male structure found in Mexico thus far and one of the largest worldwide, supporting the proposal of a new species based on this specimen.

Importantly, our cuticular analysis yielded the first description with morphological and anatomical characters of the genus Weltrichia 


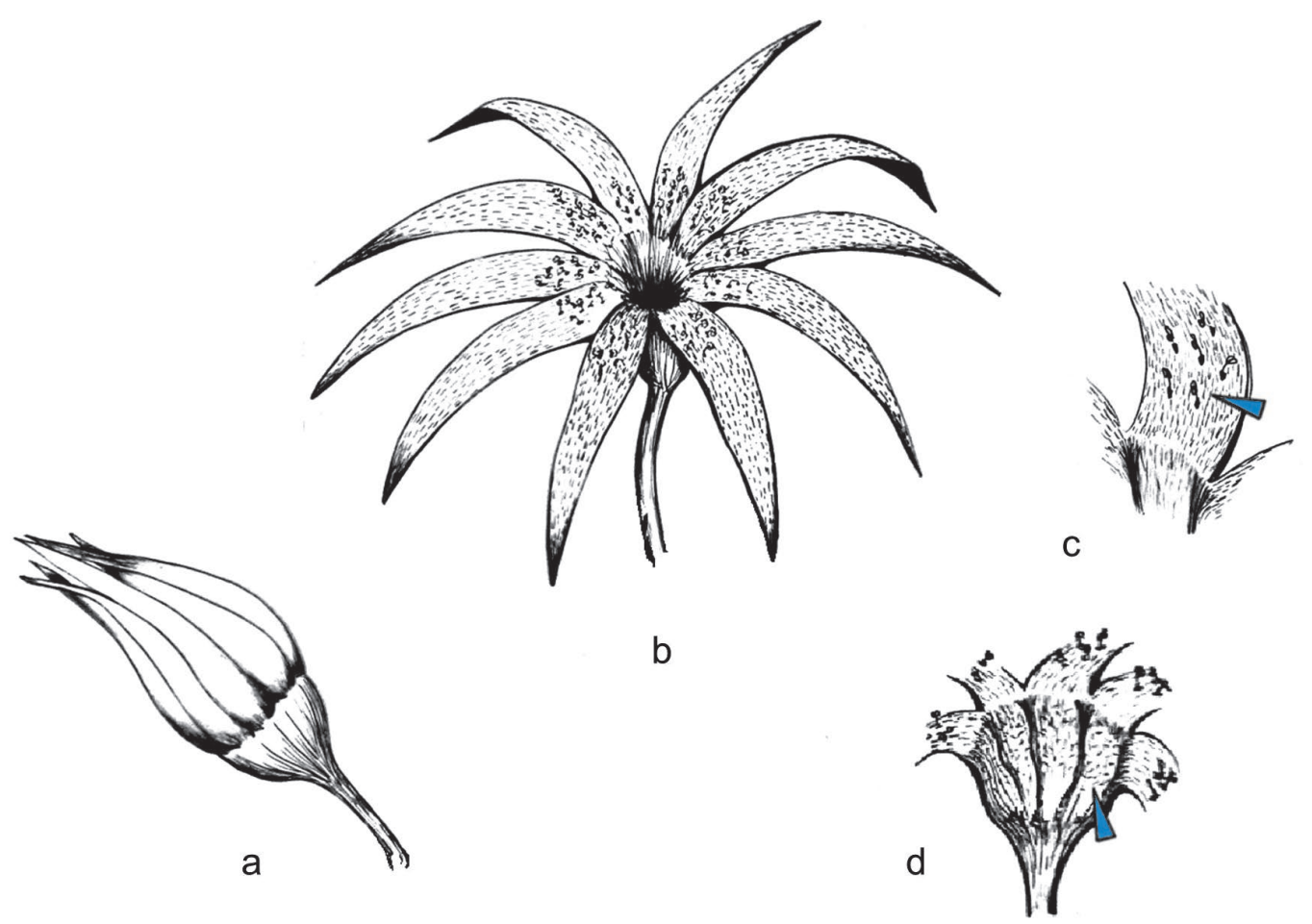

Fig. 2. Reconstruction proposed for Weltrichia magna sp. nov. a. Inmature male reproductive structure; b. Mature reproductive structure; c. Centrifugal ray, scars from pollen sacs (arrowhead); d. Internal cup detail with hairs (arrowhead). Drawing by Diana S. Guzmán-Madrid

in Mexico, and expands on previous studies of this genus. The new finding increases the species records of the paleoflora of the region and the distribution of male structures in the Jurassic of Oaxaca.

\section{ACKNOWLEDGEMENTS}

We thank M.Sc. María Berenit Mendoza Garfias and Biodiversity Microscopy and Photography Laboratory 1 of the Biology Institute of the National Autonomous University of Mexico for assistance and facilities provided during the scanning electron microscope sessions and for providing of photographs of the anatomical details of the analyzed specimen. We also thank Dr. Mihai Popa and Dr. Christian Pott for their suggestions, which helped to improve the manuscript. Financial support for this study came from the Dirección de asuntos del personal académico DGAPA, proyect PAPIIT 1N100721 Paleobotanical and Geological study of the sedimentary paleo-basin of the Jurassic in the Mixtec Terrane.

\section{REFERENCES}

Anderson, J.M., Anderson, H.M., Cleal, C.J., 2007. Brief history of the Gymnosperms: classification, biodiversity, phytogeography and ecology. Strelitzia. v 20. South African National Biodiversity Institute, Pretoria.

Bose, M.N., Banerji, J., 1984. The fossil floras of Kachh. Mesozoic megafossils. The Palaeobotanist 33, 1-189.
Braun, C.F.W., 1847. Weltrichia, eine neue Gattung fossiler Rhizantheen. Flora 32, 705-712.

Campos-Madrigal, E., Centeno-García, E., Mendoza-Rosales, C.C., Silva-Romo, G., 2013. Sedimentología, reconstrucción paleoambiental y significado tectónico de las sucesiones clásticas del Jurásico Medio en el área de Texcalapa, Puebla-Huajuapan de León, Oaxaca: Revisión de las formaciones Ayuquila y Tecomazúchil. Revista Mexicana de Ciencias Geológicas 30(1), 24-50.

Delevoryas, T., 1991. Investigations of north American cycadeoids: Weltrichia and Williamsonia from the Jurassic of Oaxaca, Mexico. American Journal of Botany 78(2), 177-182. https://doi. org/10.1002/j.1537-2197.1991.tb15744.x

Engler, A., 1892. Anacardiaceae. In: Engler, A., Prantl, K. (eds) Die natürlichen Pflanzenfamilien, III. Leipzig: Engelmann, 138-178, 458-495

Erben, H.K., 1956. Estratigrafía y Paleontología del Mesozoico de la Cuenca Sedimentaria de Oaxaca y Guerrero. Especialmente del Jurásico Inferior y Medio. XX Congreso Geológico Internacional Excursión A-12, México, D.F., 11-36.

Guzmán-Madrid, D.S., 2016 (unpubl.). Estudio morfológico y cuticular de Mexiglossa varia del Jurásico Inferior de la formación Cuarcítica Cualac, localidad Rosario Nuevo, Oaxaca. Facultad de Estudios Superiores Zaragoza, Universidad Nacional Autónoma de México. Bachelor's Thesis, 102 pp.

Guzmán-Madrid, D.S., Velasco-De León, M.P., LozanoCarmona, D.E., 2019. Nuevo registro de Weltrichia Braun, 1847 emend. Harris, 1969 del Jurásico de Oaxaca (summary), in Paleontología Mexicana, 
Número especial, 5: XVI Congreso Nacional de Paleontología. Chihuahua 2019, I Simposio de Paleobotánica y Palinología. Universidad Autónoma de Chihuahua, México (5), 136.

Harris, T.M., 1969. The Yorkshire Jurassic Flora. III: Bennettitales. Trustees of the British Museum (Natural History), London.

Kerp, H., 1990. The study of fossil gymnosperms by means of cuticular analysis. Palaios 5, 548-569. https://doi.org/10.2307/3514861

Kimura, T., Ohana, T., 1989. Late Jurassic plants from the Oginohama formation, Oshika group in the outer zone of Northeast Japan (II). Bulletin of the National Science Museum 15, 53-70.

Kouwenberg, L.L.R., Hines, R.R., McElwain, J.C., 2007. A new transfer technique to extract and process thin and fragmented fossil cuticle using polyester overlays. Review of Palaeobotany and Palynology 145, 243-248. https://doi.org/10.1016/j. revpalbo.2006.11.002

Krasser, F., 1919. Ein neuen Typus einen mannlichen Williamsonia - Becherblute aus der Alpinen Trias. Sitzungsberichte der Kaiserlichen Akademie der Wissenschaften. Mathematisch-Naturwissenschaftliche Classe, Abt. I 128, 1-10.

Labandeira, C.C., 1997. Insect Mouthparts: Ascertaining the Paleobiology of insect Feeding Strategies. Annual Review of Ecology and Systematics 28, 153-193. https://doi.org/10.1146/annurev.ecolsys.28.1.153

Labandeira, C.C., 1998. Early history of arthropod and vascular plant associations. Annual Review of Earth and Planetary Sciences 26, 329-377. https:// doi.org/10.1146/annurev.earth.26.1.329

Li, N., Li, Y., Wang, L.X., Zheng, S.L., Zhang, W., 2004. A new species of Weltrichia Braun in North China with a special bennettitalean male reproductive organ. Acta Botanica Sinica 46(11), 1269-1275.

Lozano-Carmona, D.E., 2017 (unpubl.). Distribución y Taxonomía de Ginkgoales (Engler, 1897) y grupos afines del Jurásico del Sur de México. Facultad de Estudios Superiores, Zaragoza. Universidad Nacional Autónoma de México. MSc theses, 92 pp.

Morán-Zenteno, D.J., Caballero-Miranda, C.I., SilvaRomo, G., Ortega-Guerrero, B., Gonzáles-Torres, E., 1993. Jurassic-Cretaceous Paleogeographic evolution of the northern Mixteca terrane, southern Mexico. Geofísica Internacional 32(3), 453-473. https:// doi.org/10.22201/igeof.00167169p.1993.32.3.522

Nathorst, A.G., 1913. How are the names Williamsonia and Wielandiella to be used? A question of nomenclature. Geologiska Föreningen i Stockholm Förhandlingar 35, 361-366. https://doi. org/10.1080/11035891309443477

Ollerton, J., 1999. La evolución de las relaciones polinizador-planta en los artrópodos. Boletín de la SEA (Sociedad Entomológica Aragonesa) 26, 741-758.

Pal, A.K., Ghosh, S.C., 1985. Weltrichia (male Williamsonia) from the borehole samples of Malda, West Bengal. Current Science 54, 574-576.
Parrish, J.T., Peterson, F., Turner, C.E., 2004. Jurassic "savannah" - plant taphonomy and climate of the Morrison Formation (Upper Jurassic, Western USA). Sedimentary Geology 167, 137-162. https:// doi.org/10.1016/j.sedgeo.2004.01.004

Peris, D., Labandeira, C.C., Peñalver, E., Delclós, X., Barrón, E., Pérez-De La Fuente, R., 2017. The case of Darwinylus marcosi (Insecta: Coleoptera: Oedemeridae): A Cretaceous shift from a gymnosperm to an angiosperm pollinator mutualism. Communicative \& Integrative Biology 10, e1325048. https:// doi.org/10.1080/19420889.2017.1325048

Person, C.P., Delevoryas, T., 1982. The middle Jurassic flora of Oaxaca, Mexico. Palaeontographica Abt. B 180(4-6), 82-119.

Popa, M.E., 2001. Aspects of Romanian Early Jurassic palaeobotany and palynology. Part IV. A new species of Weltrichia from Anina. Studia Universitatis Babeş-Bolyai, Geologie XLVI, 69-76. https://doi. org/10.5038/1937-8602.46.2.6

Popa, M.E., 2014. Early Jurassic bennettitalean reproductive structures of Romania. Palaeobiodiversity and Palaeoenvironments 94 (2), 327-362. https:// doi.org/10.1007/s12549-014-0165-9

Popa, M.E., 2019. Review of the bennettitalean genus Weltrichia. Journal of Palaeogeography 8, 12. https://doi.org/10.1186/s42501-019-0023-9

Pott, C., 2014. A revision of Wielandiella angustifolia, a shrub-sized bennettite from the Rhaetian-Hettangian of Scania, Sweden, and Jameson Land, Greenland. International Journal of Plant Sciences 175(4), 467-499. https://doi.org/10.1086/675577

Pott, C., Schmeissner, S., Dutsch, G., Van Konijnenburgvan Cittert, J.H.A., 2016. Bennettitales in the Rhaetian flora of Wustenwelsberg, Bavaria, Germany. Review of Palaeobotany and Palynology 232, 98-118. https://doi.org/10.1016/j.revpalbo.2016.04.010

Sandoval, J., Westermann, G.E.G., 1986. The Bajocian (Jurassic) ammonite fauna of Oaxaca, Mexico. Journal of Paleontology 60, 1220-1271. https://doi. org/10.1017/s0022336000002985

Saporta, G., 1891. Paléontologie francaise ou description desfossils de la France (2, Végétaux). Plant Jurassiques IV, 355-548.

Schweitzer, H.J., 1977. Die Rhato-Jurassischen Floren des Iran und Afganistans 4. Die ratische Zwitterblute Irania hermaphroditica nov. spec. Und ihre Bedenirtrung fur die Phylogenie du Angiospermen. Palaeontographica Abt. B 161, 98-145.

Schweitzer, H.J., Kirchner, M., 2003. Die Rhato-Jurassichen Floren des Iran und Afghanistans. 13. Cycadophyta III. Bennettitales. Palaeontographica Abt. B 264, 1-166.

Silva-Pineda, A., 1984. Revisión taxonómica y tipificación de las plantas jurásicas colectadas y estudiadas por Wieland (1914) en la región de El Consuelo, Oaxaca. Paleontología Mexicana 49, 1-103.

Silva-Pineda, A., Velasco-De León, M.P., Gil, J.A., Grimaldo, J.R., 2011. Una nueva especie de Weltrichia (Bennettitales) del Jurásico Medio de la Formación 
Tecomazuchil (Oaxaca, México). Geobios 44(5), 519_ 525. https://doi.org/10.1016/j.geobios.2011.01.004

Sitholey, R.V., Bose, M.N., 1953. Williamsonia Santalensis sp. nov. a male fructification from the Rajmahal series, with remarks on the structure of Ontheanthus polyandra Ganju. Birbal Sahni Institute of Palaeobotany, Lucknow, 2, 29-39.

Sun, G., Zheng, S.L., Dilcher, D.L., Wang, Y.D., Mei, S.H., 2001. Early angiosperms and their associated plants from Western Liaoning, China, Shanghai: Scientific and Technological Education Publishing House (in Chinese).

Taylor, T.N., Taylor, E.L., Krings, M., 2009. Paleobotany. The biology and evolution of fossil plants. Academic Press, Amsterdam.

Velasco-De León, M.P., Ortíz-Martínez, E.L., SilvaPineda, A., 2012. La distribución de las Bennettitales y sus estructuras reproductoras en el terreno Mixteco. Paleontologia Mexicana 62, 159-165.

Weber, R., 2008. Dictyotrichia gen. nov., Haitingeria Krasser, y otros órganos reproductivos o apendicu- lares de cicadofitas, Triásico Tardío, Sonora, México. In: Weber, R. (ed.), Plantas triásicas y jurásicas de México: Universidad Nacional Autónoma de México, Instituto de Geología, B 115 III, pp. 117-149.

Weber, R., Zambrano, G.A., 1985. Nuevo ensayo de un panorama de la paleoecología de comunidades de la Tafoflora Santa Clara (Triásico Tardío, Sonora). In: Weber, R. (ed.), III Congreso Latinoamericano de Paleontología, Simposio sobre floras del Triásico Tardío, su fitogeografía y paleoecología: Universidad Nacional Autónoma de México. Instituto de Geología. Oaxtepec, Mor., pp. 153-163.

Weber, R., Zambrano-García, A., Amozurrutia-Silva, F., 1980. Nuevas contribuciones al conocimiento de la Tafoflora de la Formación Santa Clara (Triásico Tardío) de Sonora. Universidad Nacional Autónoma de México. Instituto de Geología V 4(2), 125-137.

Wieland, G.R., 1914. La flora Liásica de la Mixteca Alta. Boletín del Instituto Geológico de México (31), $1-165$. 